\title{
Maharaja Adhiraja Bijay Chand Mahtab of Burdwan
}

The news of the death in Calcutta on 29th August, 1941, of Sir Bijay Chand Mahtab, Maharaja Adhiraja Bahadur of Burdwan, must have been learnt with deep regret by all members of the Royal Asiatic Society. He had been a member of the Society since 1906, and often attended its meetings during his visits to this country.

The late Maharaja, born on 19th October, 1881, was a son of Raja Ban Bihari Kapur, who was closely related to the well-known Maharaja Mahtab Chand Bahadur (1820-1879). On the death of Maharaja Aftab Chand, Bijay Chand was adopted by the widowed Maharani, and succeeded to the Estate in 1887. The family came originally from Lahore in the seventeenth century, and by the middle of the following century the Burdwan Raj had secured a pre-eminent position among the leading landholding families of Bengal. Maharaja Mahtab Chand had been a nobleman honoured not only for the help he consistently rendered to the Government of the day, but also for his educational and other charitable activities. The youthful Maharaja Bijay Chand was very carefully educated and trained for his great heritage, and with his keen intelligence and acute common sense took full advantage of his many opportunities. He travelled widely in his earlier years, and in his Diary of an European Tour displayed much power of observation. For a time it looked as if the Maharaja was aiming at a literary career. His poems and dramas in Bengali showed considerable promise, but as years passed the management of his own extensive estates, together with the calls of public duty, absorbed most of his time. In 1908, he saved the life of Sir Andrew Fraser, then LieutenantGovernor of Bengal, from an attack by a criminal assailant, and received the Indian Order of Merit. For many subsequent years he served almost continuously as a representative of the Bengal landholders in the Provincial and Imperial Legislative Councils. He was a member of the Bengal Cabinet from 1919 to 1924 , and afterwards served on several important 
Government Committees and Commissions, and he was also a representative of India at the Imperial Conference of 1926. It was as a member of the Bengal Land Revenue Commission that he paid his last visit to England in the summer of 1939. In politics, the views of the Maharaja were remarkable for his sturdy independence, clarity, and moderation of judgment, and for his far-sightedness. He won the trust and esteem both of his own countrymen and of British officials.

In spite of his numerous official and public activities, Maharaja Bijay Chand always retained an active interest in scholarly pursuits. He held high office on many occasions in the Asiatic Society of Bengal; he was a Trustee of the Indian Museum and the Victoria Memorial in Calcutta; and he belonged to various learned societies both in India and in England. The Universities of Edinburgh and Cambridge conferred honorary doctorates on him. To the last he was a generous patron of scholars and literary workers in Bengal. He was made K.C.I.E. in 1909, K.C.S.I. in 1911, and G.C.I.E. in 1924. Maharaja Bijay Chand has been succeeded by his elder son, Uday Chand Mahtab, who is a graduate of the Calcutta University and a member of the Bengal Legislative Assembly, and we wish him a career as noble and useful as that of his illustrious father.

Atul C. ChatterJee. 